\title{
Activation of TAFI on the Surface of Streptococcus pyogenes Evokes Inflammatory Reactions by Modulating the Kallikrein/Kinin System
}

\author{
Sara H. Bengtson ${ }^{a}$ Caroline Sandén ${ }^{b}$ Matthias Mörgelin ${ }^{a}$ Pauline F. Marx ${ }^{c}$ \\ Anders I. Olin $^{a} \quad$ L.M. Fredrik Leeb-Lundberg ${ }^{b}$ Joost C.M. Meijers ${ }^{c}$ \\ Heiko Herwald ${ }^{a}$ \\ a Department of Clinical Sciences, Section for Clinical and Experimental Infection Medicine, and \\ ${ }^{b}$ Department of Experimental Medical Science, Unit of Drug Target Discovery, Lund University, Lund, Sweden, and \\ 'Departments of Vascular and Experimental Vascular Medicine, Academic Medical Center, University of Amsterdam, \\ Amsterdam, The Netherlands
}

\section{Key Words}

Proteolysis - Hemostasis - Thrombosis • Vascular biology

Phagocytes

\begin{abstract}
Bacteria-controlled regulation of host responses to infection is an important virulence mechanism that has been demonstrated to contribute to disease progression. Here we report that the human pathogen Streptococcus pyogenes employs the procarboxypeptidase TAFI (thrombinactivatable fibrinolysis inhibitor) to modulate the kallikrein/ kinin system. To this end, bacteria initiate a chain of events starting with the recruitment and activation of TAFI. This is followed by the assembly and induction of the contact system at the streptococcal surface, eventually triggering the release of bradykinin (BK). BK is then carboxyterminally truncated by activated TAFI, which converts the peptide from a kinin $B_{2}$ receptor ligand to a kinin $B_{1}$ receptor (B1R) agonist. Finally, we show that streptococcal supernatants indirectly amplify the B1R response as they act on peripheral blood mononuclear cells to secrete inflammatory cytokines that in turn stimulate upregulation of the B1R on human fibroblasts. Taken together our findings implicate a critical and novel role for streptococci-bound TAFI, as it pro-
\end{abstract}

cesses BK to a B1R agonist at the bacterial surface and thereby may redirect inflammation from a transient to a chronic state.

Copyright $\odot 2008$ S. Karger AG, Basel

\section{Introduction}

Streptococcus pyogenes is an important human pathogen that normally causes harmless skin and throat infections. Although these conditions often are self-limiting, infections can become invasive and may give rise to severe complications such as streptococcal toxic shock syndrome and necrotizing fasciitis, conditions associated with high mortality [1]. This said, it was recently estimated that more than 500,000 humans die each year from $S$. pyogenes infections, which places this bacterium among the 10 most dangerous pathogens [2]. In order to cause infection, $S$. pyogenes has developed a multifold repertoire of virulence factors [3]. For example, the bacterium has a broad arsenal of secretory proteins, including exotoxins which are powerful inducers of proinflammatory cytokines such as interleukin (IL)-1 $\beta$, IL- 6 , and tumor necrosis factor- $\alpha$ (TNF$\alpha)$ [4]. In addition, streptococci also express a huge panel of surface-bound virulence factors that are involved in

\section{KARGER}

Fax +41613061234

E-Mail karger@karger.ch

www.karger.com
(C) 2008 S. Karger AG, Basel

1662-811X/09/0011-0018\$26.00/0

Accessible online at:

www.karger.com/jin 
many host/pathogen interactions such as the recruitment of host proteins to the bacterial surface or bacterial attachment to eukaryotic cells. Among these are M proteins, which were first described by Lancefield [5] in the 1930s. Today $\mathrm{M}$ and $\mathrm{M}$-like proteins are considered classical virulence factors and are probably the best-characterized surface-bound virulence determinants of S. pyogenes [6].

The human contact system (also known as the kallikrein/kinin system or the intrinsic pathway of coagulation) has recently attracted considerable attention, since the recognition pattern of contact factors functions in a manner that is remarkably similar to that seen in other innate immune systems, for instance the complement system [for review, see 7]. Subsequent work has demonstrated that activation of the contact system leads to the generation of antimicrobial peptides derived from high molecular weight kininogen (HK), a cofactor of the contact system $[8,9]$. Already a decade ago, it was reported that HK has a high affinity for many streptococcal serotypes. Studies with an M1 serotype revealed an interaction of $\mathrm{HK}$ with the respective M protein [10]. Interestingly, HK bound to the streptococcal surface via M1 protein is prone to processing by plasma kallikrein (another factor of the contact system) resulting in the release of bradykinin (BK) [11]. BK and the BK metabolite desArg${ }^{9} \mathrm{BK}$ are short peptides of nine and eight amino acids in length, respectively. Both peptides are proinflammatory mediators capable of promoting hypotension, increased vascular permeability, edema, fever, and pain. They achieve these reactions by binding and activating receptors belonging to the family of G-protein-coupled seven transmembrane-spanning receptors. While $\mathrm{BK}$ has a high affinity for the $\mathrm{B}_{2}$ receptor (B2R) subtype, desArg${ }^{9} \mathrm{BK}$ preferentially interacts with the $\mathrm{B}_{1}$ receptor $(\mathrm{B} 1 \mathrm{R})$, which shares only minor sequence homology with the $\mathrm{B} 2 \mathrm{R}$ [12]. In contrast to the $\mathrm{B} 2 \mathrm{R}$, which is constitutively expressed by many cells types, the B1R is induced only following inflammatory insult. While activation of B2R gives rise to a transient inflammatory response, stimulation of B1R promotes a sustained response [12].

The conversion of $\mathrm{BK}$ to desArg ${ }^{9} \mathrm{BK}$ is mediated by carboxypeptidases of the $\mathrm{N}$ and $\mathrm{M}$ type [13]. Interestingly, another member of the carboxypeptidase family called procarboxypeptidase $\mathrm{B}, \mathrm{R}$ or $\mathrm{U}$, better known as TAFI (thrombin-activatable fibrinolysis inhibitor), has recently been shown to assemble at the surface of streptococci of the M41 serotype [14], a strain with high affinity for HK [10]. TAFI adheres to the bacterial surface by interacting with the streptococcal collagen-like surface proteins A and B (SclA and SclB) [14]. Subsequent studies have shown that bacteria-bound TAFI is activated by its natural activators, plasmin and thrombin, which are also recruited to the streptococcal surface. As implicated by the name, TAFI impairs fibrinolysis by removing carboxy-terminal lysine residues from partially degraded fibrin that are required for tissue-type plasminogen activator-dependent plasmin formation. However, apart from its role in fibrinolysis, TAFI has been shown to cleave other substrates such as anaphylatoxins C3a and C5a [15], thrombin-cleaved osteopontin [16], and fibrinopeptide B [17]. In addition, TAFI is able to convert $\mathrm{BK}$ to desArg ${ }^{9} \mathrm{BK}$ which should be associated with a switch from a B2R ligand to a B1R agonist.

The present study was undertaken to determine whether S. pyogenes can create prerequisites for inappropriate persistent inflammatory responses by initiating a chain of events including the assembly and activation of the contact system at the bacterial surface, recruitment and activation of TAFI, conversion of BK to desArg ${ }^{9} \mathrm{BK}$ by bacteria-bound activated TAFI, and an upregulation of B1R on human fibroblasts.

\section{Materials and Methods}

Bradykinin and desArg ${ }^{9} \mathrm{BK}$ were from Bachem (Torrence, Calif., USA). Thrombin was from ICN Biomedicals Inc. (Aurora, Ohio, USA), thrombomodulin from American Diagnostica Inc. (Stamford, Conn., USA), and plasmin was purchased from Sigma (St. Louis, Mo., USA). Todd Hewitt Broth (TH) medium was from Beckton Dickinson (Sparks, Md., USA).

\section{Cell Culture}

Human fetal lung fibroblasts (IMR-90 cells) CCL-186 (American Type Culture Collection, Manassas, Va., USA) were cultured in minimum essential medium as described earlier [18]. Cells were plated at a density of $1.5 \times 10^{5}$ cells/well in 6 -well plates ( 35 $\mathrm{mm}$ well) and used at confluency after 3-4 days. Experiments were conducted in culture medium supplemented with L-glutamine alone. Human peripheral blood mononuclear cells (PBMCs) were isolated as previously described [19].

\section{Stimulation of PBMCs}

PBMCs were incubated with $1 \%(\mathrm{v} / \mathrm{v})$ S. pyogenes (M41) supernatants (obtained from overnight cultures of single colonies in 40 $\mathrm{ml} \mathrm{TH}$ medium) in RPMI 1640 medium (Invitrogen, Paisley, UK) in the presence of $2 \mathrm{mM} \mathrm{L}$-glutamine for $24 \mathrm{~h}$ at $37^{\circ} \mathrm{C}$. Cells were pelleted by centrifugation and the supernatant was assayed for IL$1 \beta$ content by ELISA (Quantikine immunoassay kit; R\&D Systems, Minneapolis, Minn., USA).

\section{Binding of Radiolabeled TAFI to Bacterial Cells}

Binding experiments of radiolabeled TAFI to the surface of the bacterial strains S. pyogenes (AP41), Staphylococcus aureus strain Wood 46, Newman, and SH1000 were performed as described before [14]. 
Degradation of HK at the Bacterial Surface

$S$. pyogenes bacteria of the M41 strain were cultured overnight in TH medium, washed and diluted to $2 \times 10^{10}$ cells $/ \mathrm{ml}$ in $10 \mathrm{mM}$ Tris buffer ( $\mathrm{pH} 7.4$ ) with $50 \mu \mathrm{M} \mathrm{ZnCl}$. The bacteria were incubated with fresh citrated human plasma $(1: 1 \mathrm{v} / \mathrm{v})$ by rotation for $1 \mathrm{~h}$ at room temperature. Bacteria were then washed and proteins bound to the bacterial surface were dissolved with $0.1 \mathrm{M}$ glycine ( $\mathrm{pH}$ 2.0). The supernatants were separated from the bacteria by centrifugation. Recovered proteins were mixed with SDS sample buffer (reducing conditions) and separated by $10 \%(\mathrm{w} / \mathrm{v})$ polyacrylamide gel electrophoresis followed by a transfer onto nitrocellulose and immunodetection with antibodies against $\mathrm{HK}$ as described before [20].

\section{Determination of Bradykinin}

Bacteria $\left(2 \times 10^{10}\right.$ cells/ml in HEPES buffer; 15 mM HEPES, 135 $\left.\mathrm{mM} \mathrm{NaCl}, 50 \mu \mathrm{M} \mathrm{ZnCl}_{2}, \mathrm{pH} 7.4\right)$ were incubated with fresh citrated plasma $(1: 1 \mathrm{v} / \mathrm{v})$ or medium. After a 15 -min incubation at room temperature, bacteria were washed and resuspended in HEPES buffer followed by another 15-min incubation step. The supernatants were separated from the bacteria and immediately processed for BK concentration measurements with an ELISA kit (Markit-M Bradykinin, Dainippon Sumitomo Pharmaceutical Co., Ltd., Osa$\mathrm{ka}$, Japan) according to the instructions of the manufacturer.

\section{Activation of TAFI by Plasmin or Thrombin/}

\section{Thrombomodulin}

Recombinant TAFI was produced as described before [21]. A quadruple mutant of TAFI (T325I, T329I, H333Y, H335Q) was generated and expressed. After activation, this mutant displayed a $~ 50$-fold enhanced stability. Details will be described elsewhere. TAFI (20 nM) was activated by a premixture of thrombin $(16 \mathrm{nM})$ and thrombomodulin $(32 \mathrm{nM})$ or plasmin $(10 \mu \mathrm{g} / \mathrm{ml})$ as described earlier [22].

\section{High Pressure Liquid Chromatography (HPLC)}

Bacteria were pre-incubated with either plasmin $(10 \mu \mathrm{g} / \mathrm{ml})$, thrombin $(16 \mathrm{nM})$ and thrombomodulin $(32 \mathrm{nM})$, or TAFI $(20 \mathrm{nM})$ (wild-type or IIYQ) for $1 \mathrm{~h}$ on ice in PBSAT (phosphate-buffered saline with $0.02 \%(\mathrm{w} / \mathrm{v})$ sodium azide and $0.05 \%(\mathrm{v} / \mathrm{v})$ Tween 20$)$. Thereafter, bacteria were washed and re-dissolved in $100 \mathrm{mM}$ HEPES buffer with $0.01 \%(\mathrm{v} / \mathrm{v})$ Tween $20(\mathrm{pH} 8)$ and $5 \mathrm{mM} \mathrm{CaCl}_{2}$, and incubated with either plasmin $(10 \mu \mathrm{g} / \mathrm{ml})$, thrombin $(16 \mathrm{nM})$ and thrombomodulin $(32 \mathrm{nM})$, or TAFI (20 nM; wild-type or IIYQ). After $20 \mathrm{~min}$ at room temperature, samples were either washed or directly further incubated with $1 \mu \mathrm{M} \mathrm{BK}$ for $15 \mathrm{~min}$ at $37^{\circ} \mathrm{C}$. Sample supernatants were then chromatographed by reverse-phase HPLC on a C18 column $(5 \mu \mathrm{m} ; 250 \times 4.6 \mathrm{~mm})$ with a linear gradient system, $100 \%$ buffer A $(0.1 \%(\mathrm{v} / \mathrm{v})$ trifluoroacetic acid (TFA) in water) to $100 \%$ buffer B $(0.1 \%$ (v/v) TFA in acetonitril). Samples were run for $45 \mathrm{~min}$ with a flow rate of $1 \mathrm{ml} / \mathrm{min}$. The UV absorbance was monitored at $214 \mathrm{~nm}$. Data were analyzed with the software package TotalChrom v6.2.0.0.1 with LC instrument Control (PerkinElmer, Waltham, Mass., USA).

\section{Radioligand Binding}

The binding of $1 \mathrm{nM}\left[{ }^{3} \mathrm{H}\right]$ desArg ${ }^{10}$ kallidin $(77.5 \mathrm{Ci} / \mathrm{mmol}$; PerkinElmer) to IMR-90 cells was performed as described earlier [18]. Binding assays were conducted on ice in triplicate and nonspecific binding was defined as the amount of radiolabeled ligand bound in the presence of $1 \mu \mathrm{M}$ non-radiolabeled desArg${ }^{10}$ kallidin.

\section{Transmission Electron Microscopy}

Proteins and peptides were labeled with colloidal gold as previously described [23]. To study complex formation, gold-labeled TAFI $(40 \mathrm{~nm})$ was mixed with either gold-labeled BK $(15 \mathrm{~nm})$ or gold-labeled desArg ${ }^{9} \mathrm{BK}(15 \mathrm{~nm})$. Alternatively, gold-labeled TAFI was incubated with plasmin in the presence of AP41 bacteria ( $1 \%$ bacterial solution) for $20 \mathrm{~min}$ at room temperature followed by the addition of gold-labeled BK. Specimens were then adsorbed for 1 min onto carbon-coated grids. The grids had been rendered hydrophilic by glow discharge at low pressure in air beforehand, briefly washed with water, and stained with $0.75 \%$ (w/w) uranyl formate in water. The samples were analyzed in a Jeol 1200 EX electron microscope operated at $60 \mathrm{kV}$ accelerating voltage. Evaluation of the data was based on 300 particles from different electron micrographs. As control, gold particles treated with polyethylene glycol alone were used and did not result in significant unspecific background binding (data not shown).

\section{Phosphoinositol Hydrolysis}

For phosphoinositol (PI) hydrolysis, HEK293 cells (human embryonic kidney cells) stably transfected with B1R [24] were employed and PI hydrolysis was measured as described earlier [25]. Briefly, cells were labeled with $1 \mu \mathrm{Ci} / \mathrm{ml}$ myo- $\left[{ }^{3} \mathrm{H}\right]$ inositol in $\mathrm{DMEM} / 10 \% \mathrm{FBS}$ for $20-24 \mathrm{~h}$ at $37^{\circ} \mathrm{C}$, washed 4 times in DMEM, and then further incubated in DMEM for $1 \mathrm{~h}$ at $37^{\circ} \mathrm{C}$. This was followed by incubation with various stimuli $\left(10 \mu \mathrm{M}\right.$ desArg ${ }^{9} \mathrm{BK}$ with or without $1 \mu \mathrm{M}$ [3,4-prolyl-3,4-(3)H(N)]-[des-Arg10,Leu9] kallidin (DLKD) a B1R antagonist, $1 \mu \mathrm{M}$ DLKD alone, sample supernatants with or without $1 \mu \mathrm{M}$ DLKD, or medium alone) in DMEM supplemented with $50 \mathrm{mM} \mathrm{LiCl}$ for $30 \mathrm{~min}$ at $37^{\circ} \mathrm{C}$. Cells were then lysed with $0.1 \mathrm{M}$ formic acid for $20 \mathrm{~min}$ at $4^{\circ} \mathrm{C}$, transferred to Eppendorf tubes, and centrifuged at 16,100 $g$ for $5 \mathrm{~min}$ at $4^{\circ} \mathrm{C}$. The supernatants were added to anion exchange columns, which were washed twice with a low-salt solution $(60 \mathrm{mM}$ ammonium formate, $5 \mathrm{~mm}$ sodium borate). Inositol phosphates were then eluted with a high-salt solution (1 M ammonium formate, $0.1 \mathrm{M}$ formic acid) and counted for radioactivity in a Beckman LS 6000 scintillation counter. Each condition was run in triplicate.

\section{Determination of desArg ${ }^{9} B K$ and Related Masses by}

MALDI-TOF Mass Spectrometry

The peptide-containing solutions were desalted and concentrated using C18 ZiptipsT (Millipore) according to the manufacturer's instructions. Briefly, the microcolumns were washed with $0.1 \%$ TFA and eluted with $1 \mu \mathrm{l} 50-90 \%$ acetonitrile in $0.1 \%$ TFA directly onto a MALDI Anchorchip ${ }^{\mathrm{TM}}$ target plate pre-spotted with $1 \mu l 2 \mathrm{mg} / \mathrm{ml}$ 2,5-dihydrobenzoic acid (DHB) in 50\% acetonitrile/0.1\% TFA. The MALDI target plate was loaded into a Bruker Reflex ${ }^{\mathrm{TM}}$ III MALDI-TOF mass spectrometer (Bruker Daltonic $\mathrm{GmbH}$, Bremen, Germany). The polarity of the instrument was set for positive ions with a delayed extraction and the detector for reflector mode. The acceleration voltage was $25 \mathrm{kV}$ and $50-75$ shots/ sample were summed in each spectrum for an improved signal-tonoise ratio. Spectra were externally calibrated using trypsin autolysis fragments (from a parallel experiment handled as above). Evaluated machine-specific protocols and settings for the mass spectrometer were used for calibration and data collection. 
Spectra were searched for $\mathrm{BK}$ and desArg ${ }^{9} \mathrm{BK}$ (including their 3 hydroxyproline equivalents and their $\mathrm{Na}^{+}-, \mathrm{Ca}^{2+}$ - and $\mathrm{Zn}^{2+}$ - adduct variants, respectively) masses.

\section{Results}

Binding of TAFI to the Surface of S. pyogenes

A common feature of pathogenic bacteria is their ability to induce strong inflammatory reactions in the human host by interfering with so-called host-effector systems. In particular, cell-mediated immune systems, complement, coagulation, and fibrinolysis are important targets that, when systemically activated, often significantly contribute to the pathology of the disease. TAFI is considered to be an important inflammatory mediator and previous studies have shown that the protein is absorbed by many different streptococcal serotypes [14]. In the present study we wished to extend these observations and analyze whether TAFI is able to convert BK to des$\mathrm{Arg}^{9} \mathrm{BK}$ at the streptococcal surface. In respect to bacteria-induced contact activation, it is noteworthy to mention that S. aureus, another important Gram-positive pathogen, has previously been reported to utilize the contact system for the generation of BK $[20,26]$. Thus, it was tempting to speculate that $S$. aureus may also employ TAFI to generate a B1R agonist by cleaving BK on its surface. To this end, we compared the binding of TAFI to a $S$. pyogenes strain of M serotype 41 (AP41) and three $S$. aureus strains (Newman, Wood 46, and SH 1000). However, while a significant binding of TAFI to $S$. pyogenes (AP41) bacteria was recorded ( $>20 \%$, data not shown), no interaction between the three staphylococcal strains and TAFI was found ( $<5 \%$, data not shown). These data suggest that the ability of AP41 bacteria to interact with TAFI is not shared by its Gram-positive relative S. aureus.

\section{Bradykinin Is Released from the Streptococcal Surface} after Incubation with Human Plasma

Based on the results obtained from the binding assays, we decided to focus on the streptococcal AP41 strain throughout this study. To investigate whether streptococcal-recruited TAFI can act as a kininase, we tested the ability of AP41 bacteria to assemble and activate the contact system at their surface. By conducting Western-blot analysis we found that upon incubation with plasma, HK is absorbed by AP41 bacteria. Figure 1A shows that the $\mathrm{HK}$, recovered from the surface of AP41 bacteria by an acid washing step, was processed into heavy and light chains suggesting the release of BK. We therefore ana-

S. Pyogenes-Bound TAFI Modulates the Contact System lyzed whether the processing of HK into the two chains is followed by the generation of BK. AP41 bacteria were incubated with plasma for $15 \mathrm{~min}$ followed by a washing step to remove unbound plasma proteins. Bacteria were then resuspended in HEPES buffer and incubated for another $15 \mathrm{~min}$ to allow contact activation and the release of BK from the bacterial surface into the liquid phase. When the BK content in the resulting supernatants was analyzed by ELISA measurements, we detected increased BK levels in supernatants from plasma, but not buffertreated bacteria (fig. 1B). Taken together, the results indicate that the human contact system can be assembled and activated at the surface of $S$. pyogenes bacteria of the M41 serotype, which is followed by the cleavage of HK and generation of BK.

Activation of TAFI at the Streptococcal Surface and Conversion of $B K$ to des $A r g^{9} B K$

We next investigated whether BK is a substrate for activated TAFI in the absence of AP41 bacteria. BK and plasmin-activated TAFI were incubated for $15 \mathrm{~min}$ at $37^{\circ} \mathrm{C}$ followed by HPLC analysis of the resulting BKcleavage products. We found that this treatment led to a complete conversion of BK to desArg ${ }^{9} \mathrm{BK}$ (fig. 2C). Similar findings were recorded when the experiments were performed with thrombin/thrombomodulin-activated TAFI (data not shown). Commercially available BK and desArg ${ }^{9} \mathrm{BK}$ were used as controls (fig. 2A, B). It should also be noted that our results are in line with earlier reports by Myles et al. [16]. In the next series of experiments, we analyzed the TAFI-induced generation of des$\mathrm{Arg}^{9} \mathrm{BK}$ at the surface of AP41 bacteria. Thus, bacteria were incubated with plasmin for $1 \mathrm{~h}$ on ice, followed by a washing step to remove unbound plasmin. TAFI was then added and after a 20-min incubation at room temperature to allow activation of TAFI by AP41-bound plasmin, BK was introduced to the reaction mixture for 15 $\min$ at $37^{\circ} \mathrm{C}$. Thereafter, supernatants were subjected to HPLC analysis and BK degradation products were measured. As seen before in the absence of bacteria, we found that also under these experimental conditions, BK is readily cleaved by activated TAFI yielding to the generation of desArg ${ }^{9} \mathrm{BK}$ (fig. 2D) and complete consumption of BK. The same results were also obtained when plasmin was replaced with thrombin/thrombomodulin in these experiments (data not shown). Even though our results show that the TAFI activators (plasmin and thrombin/ thrombomodulin) are bound to the bacterial surface, the experimental settings used did not allow us to distinguish between desArg ${ }^{9} \mathrm{BK}$ generation at the bacterial sur- 


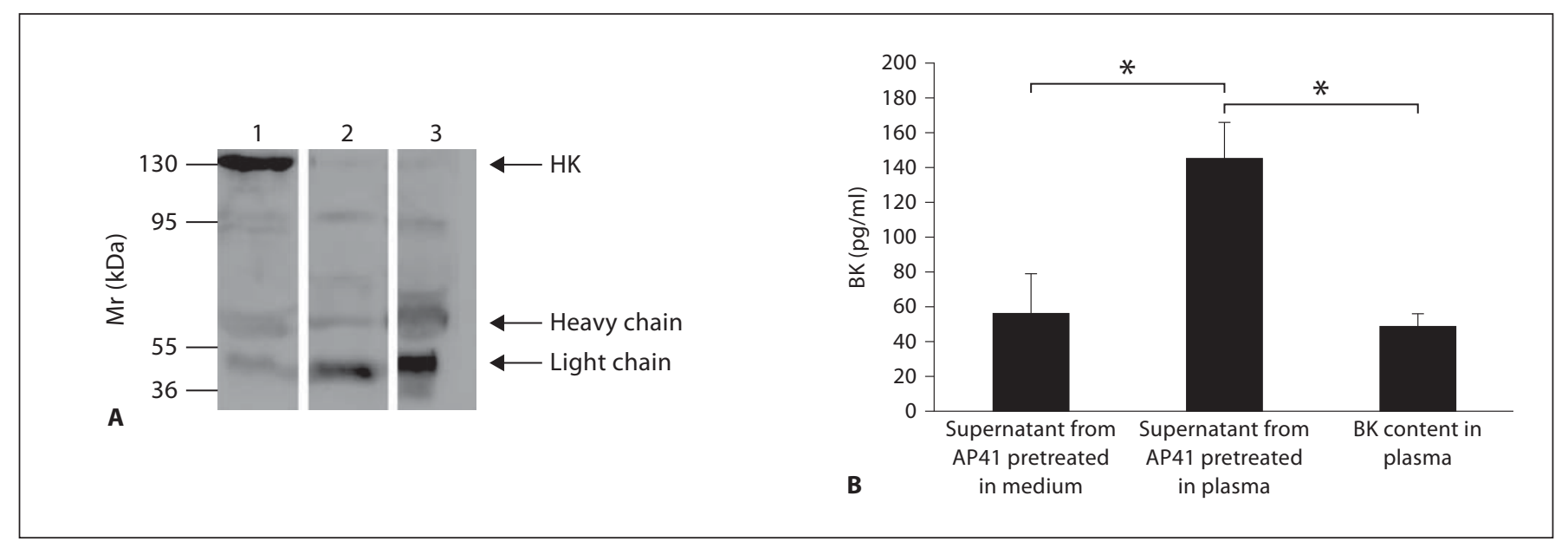

Fig. 1. Processing of $\mathrm{HK}$ and release of $\mathrm{BK}$ at the bacterial surface. A S. pyogenes bacteria of serotype M41 were incubated with human plasma for $60 \mathrm{~min}$ followed by a washing step to remove unbound proteins. Bacteria-absorbed proteins were eluted with an acid wash and the recovered proteins were subjected to Western blot analysis and immunodetection with antibodies against $\mathrm{HK}$. Lane 1 = Normal human plasma; lane 2 = kaolin-treated human plasma, which leads to a complete cleavage of HK into its heavy and light chain; lane 3 = proteins absorbed from plasma by $S$. pyo-

face or in solution, since activated TAFI could theoretically have been dissociated from the streptococci. This issue could have been solved by introducing a second washing step before adding BK. However, since the halflife time of activated TAFI is rather short, we found that an additional washing step was combined with a complete loss of TAFI's enzymatic activity. To confirm that the interaction between TAFI and BK indeed takes place at the bacterial surface, we employed negative staining electron microscopy. First, we wished to validate the experimental approach and studied the complex formation between colloidal gold-labeled TAFI $(40 \mathrm{~nm})$ and colloidal gold-labeled BK $(15 \mathrm{~nm})$ in the absence of bacteria. Figures $3 \mathrm{~A}$ and $\mathrm{C}$ show that most TAFI molecules are in contact with BK whereas gold-labeled TAFI failed to physically interact with gold-labeled desArg ${ }^{9} \mathrm{BK}$ (15 nm; fig. $3 \mathrm{~B}$ ), implicating that the gold label does not disturb the binding of BK to TAFI nor does it affect the specificity of TAFI. The experiments therefore show that negative staining electron microscopy is a suitable technique for studying the interaction between TAFI and BK. We then tested the complex formation between gold-labeled TAFI and gold-labeled BK at the bacterial surface. To this end, AP41 bacteria were first incubated with plasmin as described before. Afterwards, gold-labeled TAFI was genes. B Bacteria were incubated with medium or plasma for 15 min followed by a washing step to remove unbound proteins. Bacteria were then resuspended in buffer for another $15 \mathrm{~min}$ to allow activation of the contact system and the release of BK into the liquid phase. Supernatants were collected and BK concentrations were determined by ELISA. The BK content in the plasma samples used for the experiments was measured and considered as background. Values are means \pm standard deviations $(\mathrm{n}=3) .{ }^{*} \mathrm{p}<$ 0.01 by Student's $t$ test. added and after a 20-min incubation at room temperature gold-labeled BK was given to the mixture. Samples were then adsorbed onto grids and subjected to negativestaining electron microscopy analysis. Figure 4 demonstrates that activated TAFI, attached at the streptococcal surface, is able to form complexes with BK.

Having demonstrated that TAFI interacts with BK at the surface of AP41 bacteria, we next wanted to show that this interaction is followed by the generation of des$\mathrm{Arg}^{9} \mathrm{BK}$. We therefore introduced a TAFI mutant (TAFIIIYQ), which has been shown to have an extended proteolytic activity ( $\sim 50$-fold more stable) when compared with wild-type TAFI. Thus, experiments with TAFI-IIYQ and $\mathrm{BK}$ in the presence of bacteria were performed as described above, with the exception that a washing step was included after incubation with TAFI-IIYQ and before adding BK (data not shown). When analyzing the resulting BK cleavage products by HPLC, it was found that more than half of the BK was converted to desArg ${ }^{9} \mathrm{BK}$ under these experimental conditions (fig. 5A). When the experimental settings were changed in that TAFI-IIYQ was given before the addition of plasmin, we also recorded that most of the BK was cleaved to desArg ${ }^{9} \mathrm{BK}$ (fig. $5 \mathrm{~B}$ ). Finally, we wished to test whether the formation of desArg ${ }^{9} \mathrm{BK}$ can take place in plasma without adding addi- 


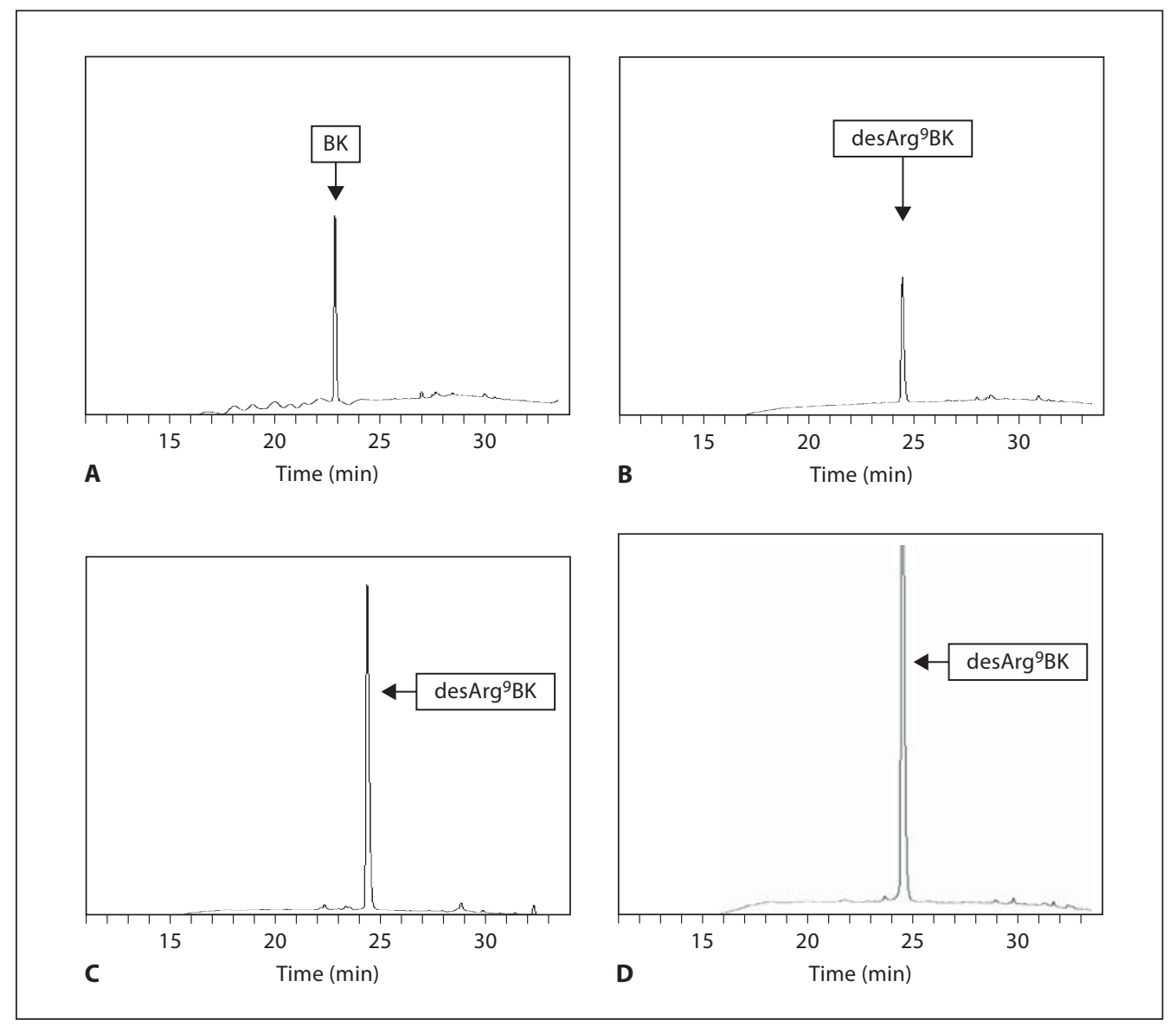

Fig. 2. Detection of BK and desArg9BK by HPLC. Commercially available BK $(1 \mu \mathrm{M} ; \mathbf{A})$ and desArg ${ }^{9} \mathrm{BK}(1 \mu \mathrm{M} ; \mathbf{B})$ were analyzed by HPLC. BK $(1 \mu \mathrm{M})$ was incubated with plasmin-activated TAFI $(20$ $\mathrm{nM}$ ) for $15 \mathrm{~min}$ followed by HPLC analysis of BK cleavage products $(\mathbf{C})$. AP41 bacteria $\left(2 \times 10^{9}\right.$ cells $\left./ \mathrm{ml}\right)$ were incubated with $(10$ $\mu \mathrm{g} / \mathrm{ml}$ ) plasmin for $60 \mathrm{~min}$ on ice, followed by a washing step to

tional BK or TAFI. We therefore pre-incubated AP41 bacteria with plasmin for $15 \mathrm{~min}$ followed by a washing step to remove unbound plasmin. Bacteria were then incubated with human plasma which should according to our hypothesis result in an activation of the contact system at the bacterial surface and subsequent release of BK, which in turn should be converted to desArg ${ }^{9} \mathrm{BK}$ by plasminactivated TAFI that has been recruited from plasma as well. $15 \mathrm{~min}$ after bacteria had been incubated with plasma, they were washed and resuspended with buffer to allow a dissociation of desArg ${ }^{9} \mathrm{BK}$ form the bacterial surface into supernatant. Supernatants were then collected and subjected to MALDI-TOF mass spectrometry. Interpretation of spectra patterns revealed several peaks that correlate well with the molecular mass of $\operatorname{desArg}^{9} \mathrm{BK}$ remove unbound protein (D). This was followed by the addition of TAFI (20 nM) and after another 20-min incubation at room temperature, $\mathrm{BK}$ was added to the mixture and incubated for 15 $\min$ at $37^{\circ} \mathrm{C}$. Bacteria were removed by a centrifugation step and the supernatants were analyzed by HPLC. The HPLC chromatograms are representative of at least four separate experiments.

(data not shown), including additional hydroxylation (most likely corresponding to hydroxyproline as described elsewhere [27]). However, no peaks matching BK were detected, suggesting that BK had been completely converted to desArg ${ }^{9} \mathrm{BK}$. Taken together the results demonstrate that the conversion of $\mathrm{BK}$ to desArg ${ }^{9} \mathrm{BK}$ can be induced by activated TAFI that is attached to the bacterial surface.

TAFI-Generated desArg ${ }^{9}$ BK Function as a B1R Ligand

We next wished to investigate whether desArg ${ }^{9} \mathrm{BK}$, generated by AP41 bacteria-bound TAFI, is a biologically active B1R agonist and measured PI hydrolysis in HEK293 cells, stably transfected with B1R. As a positive control, commercially available desArg ${ }^{9} \mathrm{BK}$ was used, which when 


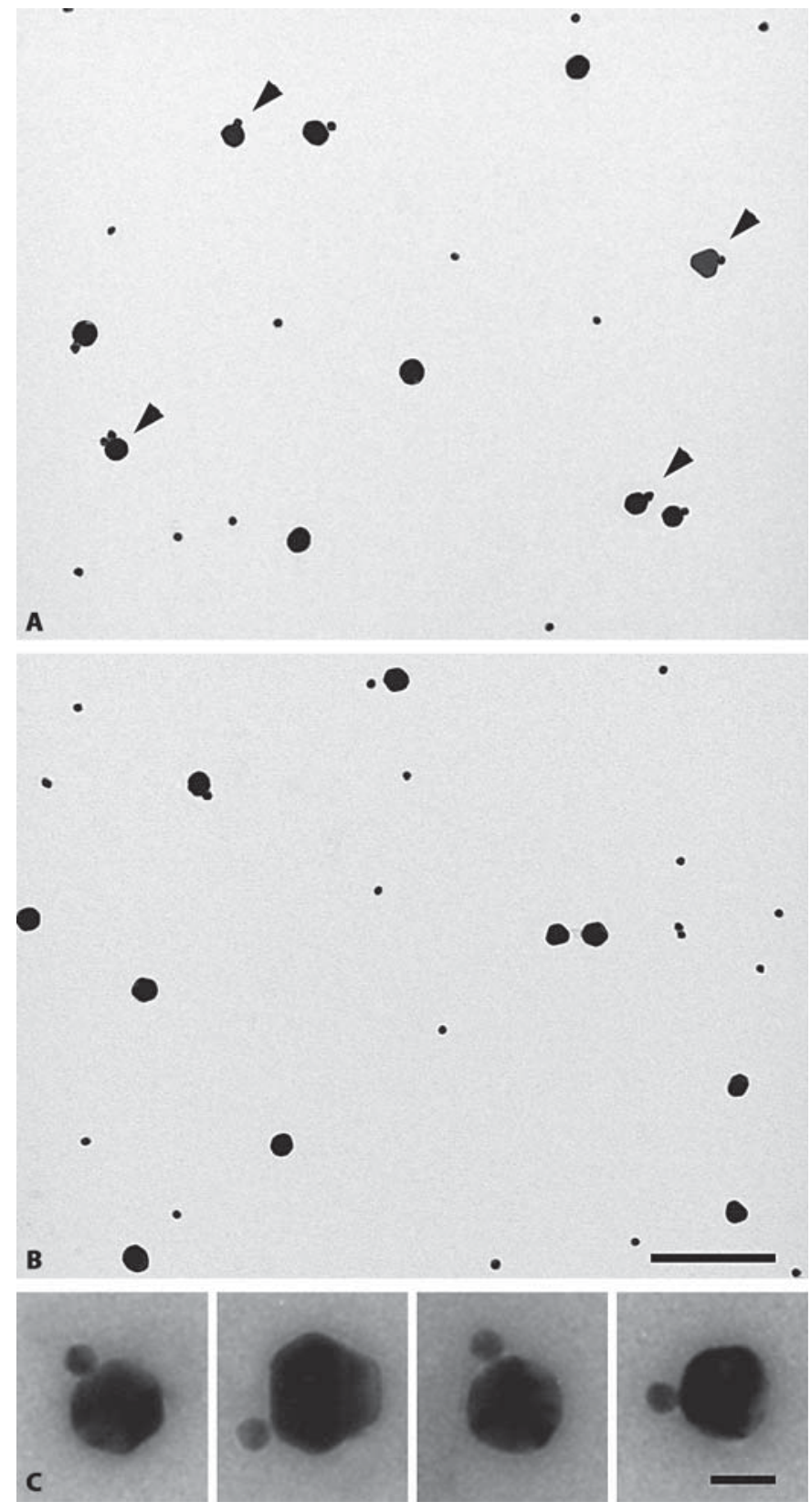

Fig. 3. Transmission electron micrograph of gold-labeled TAFI with gold-labeled BK and desArg ${ }^{9} \mathrm{BK}$. TAFI was labeled with 40 $\mathrm{nm}$ colloidal gold and incubated with $15 \mathrm{~nm}$ gold-labeled BK $(\mathbf{A})$ or desArg ${ }^{9}$ BK (B). Samples were prepared for electron microscopy by negative staining with uranyl formate. Low magnification fields of complexes are shown. Arrowheads point to gold-labeled kinins that are in complex with gold-labeled TAFI. Statistical evaluation revealed that $49 \%$ of gold-labeled TAFI were in complex with gold-labeled BK, while only $8 \%$ were associated with gold-labeled desArg ${ }^{9} \mathrm{BK}(\mathbf{C})$. Representative complexes between gold-labeled TAFI and gold-labeled $\mathrm{BK}$ are depicted in the inserts. The bar represents 200 (A, B) and $25 \mathrm{~nm}(\mathbf{C})$.
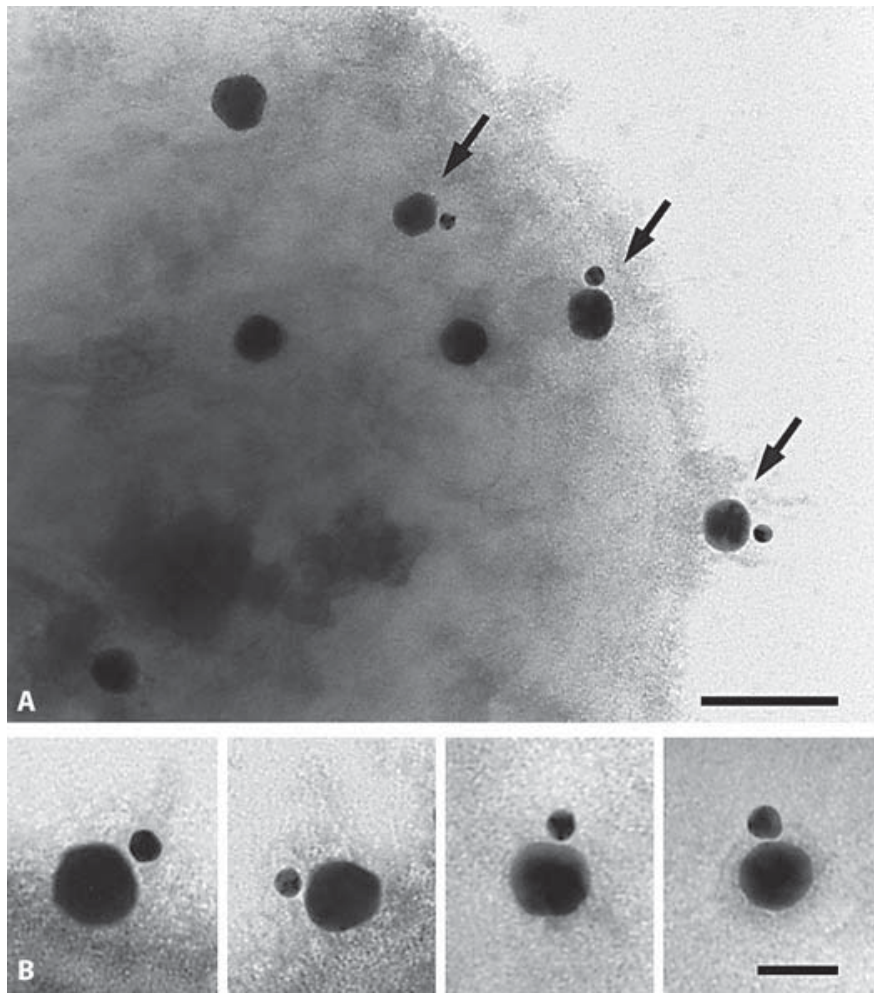

Fig. 4. Transmission electron micrograph of gold-labeled TAFI with gold-labeled BK at the surface of AP41 bacteria. A AP41 bacteria $\left(2 \times 10^{9}\right.$ cells $\left./ \mathrm{ml}\right)$ were incubated with $(10 \mu \mathrm{g} / \mathrm{ml})$ plasmin for $60 \mathrm{~min}$ on ice, followed by a washing step to remove unbound protein. This was followed by adding gold-labeled TAFI and after another 20 min gold-labeled BK was added to the mixture. Bacteria were pelleted and then subjected to negative staining electron microscopy. Arrows indicate gold-labeled TAFI in complexes with gold-labeled BK attached to the bacterial surface. B Representative complexes between gold-labeled TAFI and gold-labeled $\mathrm{BK}$ are depicted in the inserts. The bar represents $100(\mathbf{A})$ and 50 $\mathrm{nm}(\mathbf{B})$.

added at a concentration of $10 \mu \mathrm{M}$ to the transfected cells, triggered a significant increase in PI hydrolysis (fig. 6A). PI hydrolysis was completely blocked when desArg ${ }^{9} \mathrm{BK}$ was co-incubated with a selective B1R antagonist (DLKD; fig. 6A), implicating that signaling did not involve other receptors, for instance those endogenously expressed by these cells. To test whether bacteria-bound TAFI is able to convert BK to an active B1R agonist, TAFI was added to bacteria and activated with plasmin as described above. This was followed by incubation with BK for $15 \mathrm{~min}$ and a centrifugation step to remove bacteria. When the resulting supernatants were added to the B1R-transfected cells, we monitored an increase in PI hydrolysis which 


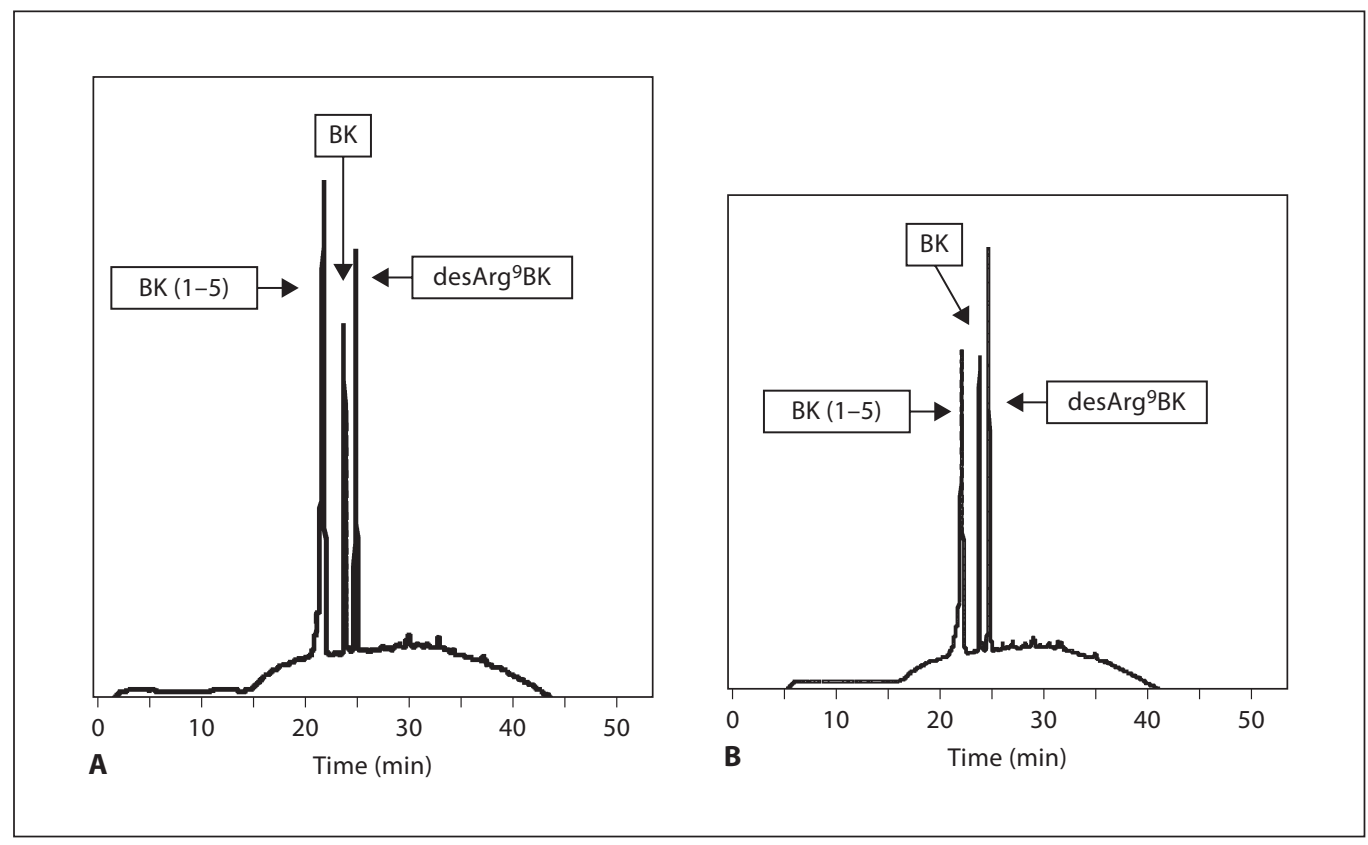

Fig. 5. Detection by HPLC of BK and desArg ${ }^{9} \mathrm{BK}$ released from AP41 bacteria. A AP41 bacteria $\left(2 \times 10^{9}\right.$ cells $\left./ \mathrm{ml}\right)$ were incubated with $(10 \mu \mathrm{g} / \mathrm{ml})$ plasmin for $60 \mathrm{~min}$ on ice, followed by a washing step to remove unbound protein. Afterwards (20 nM) TAFI-IIYQ was added for $20 \mathrm{~min}$ and after a second washing step BK was given to the mixture and incubated for $15 \mathrm{~min}$ at $37^{\circ} \mathrm{C}$. Bacteria were removed by a centrifugation step and the supernatants were analyzed by HPLC. B AP41 bacteria were first treated with TAFIIIYQ and then with plasmin. Washings steps and incubation with BK were performed as described in $\mathbf{A}$. The HPLC chromatograms are representative of at least four separate experiments.

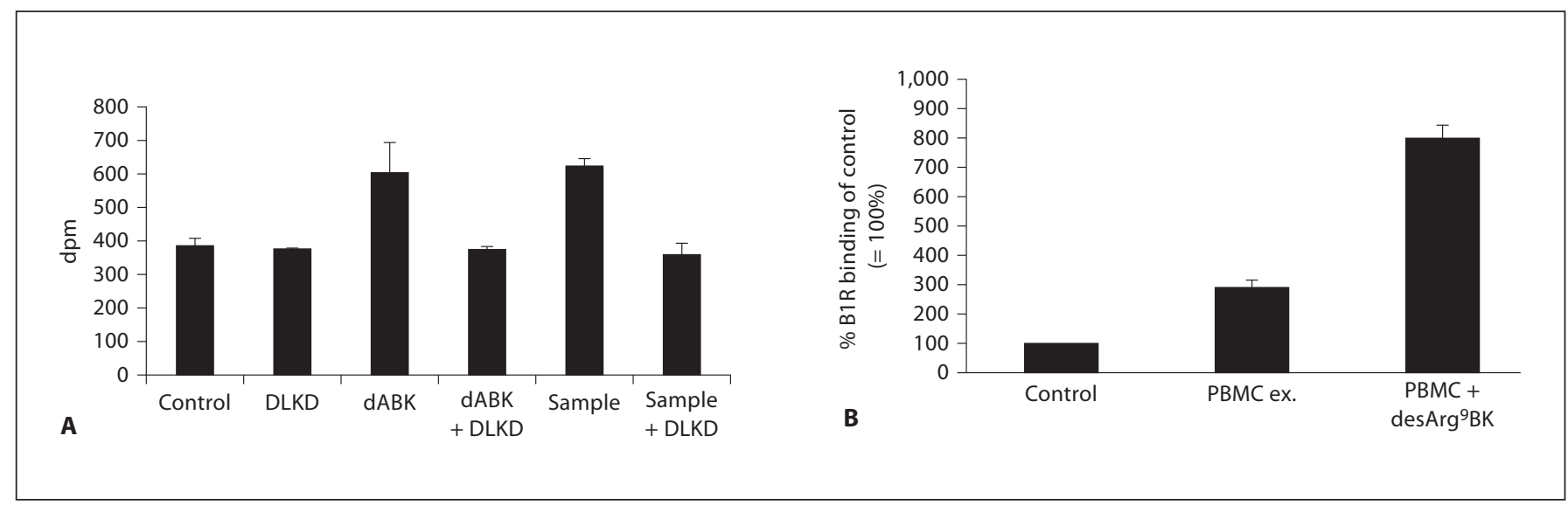

Fig. 6. Measurements of the biological activity of $\operatorname{des}^{A}{ }^{9} \mathrm{BK}$ released from AP41 bacteria and cell surface expression of B1R. A HEK293 cells stably transfected with B1R were treated with (i) buffer, (ii) the B1R antagonist DLKD, (iii) $\operatorname{des} \operatorname{Arg}^{9} \mathrm{BK}$, (iv) a mixture of desArg ${ }^{9} \mathrm{BK}$ and DLKD, (v) BK cleavage products released from AP41 bacteria, and (vi) a mixture of BK cleavage products released from AP41 bacteria and DLKD. Inositol phosphates were detected as described in Materials and Methods. The result is representative of three experiments with each point performed in duplicates. B IMR-90 cells were incubated for $6 \mathrm{~h}$ with (i) medium, (ii) PBMC exudates (monocytic cells that had been stimulated for $24 \mathrm{~h}$ with $1 \%$ S. pyogenes overnight culture supernatants), or (iii) PBMC exudates in the presence of $10 \mu \mathrm{M}$ desArg ${ }^{9} \mathrm{BK}$. All treatments were performed in MEM medium and in the absence of serum and antibiotics. After intensive washing, cells were assayed for specific $\left[{ }^{3} \mathrm{H}\right]$ des-Arg ${ }^{10}$ kallidin (B1R ligand) binding. Binding of $\left[{ }^{3} \mathrm{H}\right]$ des-Arg ${ }^{10} \mathrm{kallidin}$ to non-stimulated cells (control) was normalized to $100 \%$ within each experiment. Results represent the mean \pm standard deviation of 3 independent experiments performed in triplicates. ${ }^{*} \mathrm{p}<0.01$ by Student's t test. 


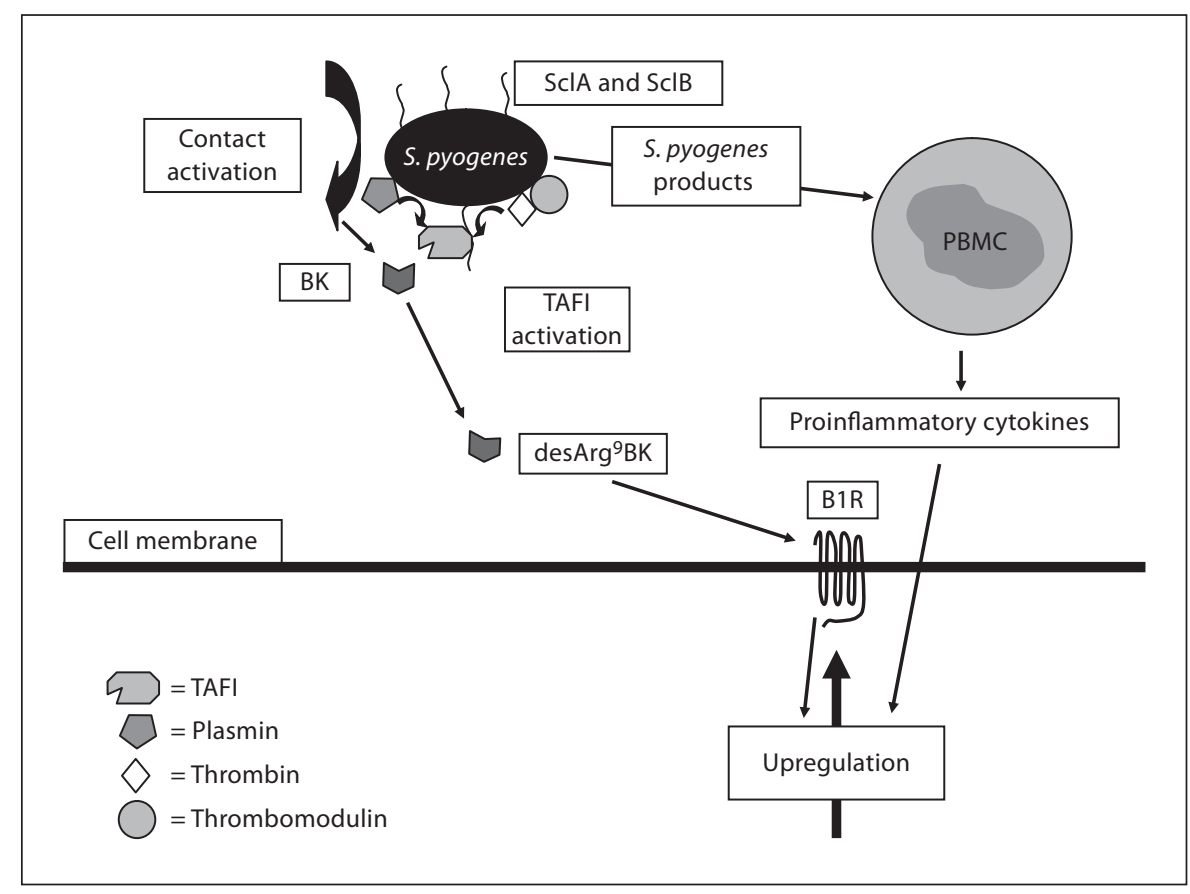

Fig. 7. Proposed mechanism used by $S$. pyogenes (AP41) to modulate the inflammatory response. Based on the present study, the following model is suggested. Plasma exudation into the infectious site will allow $S$. pyogenes bacteria to bind human TAFI via SclA and SclB. TAFI activators such as plasmin and thrombin/ thrombomodulin can also be recruited to the bacteria and trigger activation of bound TAFI. At the same time bacteria assemble and activate the factors of the contact system at their surface which

was not seen when the supernatants were given to the cells in the presence of DLKD (fig. 6A). Thus, the data show that $\mathrm{BK}$ is converted to a biologically active $\mathrm{B} 1 \mathrm{R}$ agonist at the bacterial surface.

Upregulation of the B1R on Human Fibroblasts upon Treatment with Exudates from Monocytes Stimulated with Supernatants from AP41 Bacteria

In order to cause an inflammatory reaction, des$\mathrm{Arg}^{9} \mathrm{BK}$, released from the streptococcal surface, requires available B1Rs. Most previous studies addressing B1R regulation were performed with IMR-90 cells, a human fetal lung fibroblasts cell line [for review, see 12] and it has been shown that IL-1 $\beta$ stimulates upregulation of B1Rs in these cells. Notably, streptococci secrete a number of exotoxins that are able to trigger the release of proinflammatory cytokines, including IL-1 $\beta$, from human monocytes [4]. We therefore tested whether exudates derived from human PBMCs, treated with supernatants from AP41 bacteria, can induce an upregulation of the B1R on the surface of results in the generation of BK. Invading monocytes at the infected site become activated by streptococcal secretion products, i.e. exotoxins, and evoke the secretion of proinflammatory cytokines that in turn trigger an upregulation of $\mathrm{B} 1 \mathrm{R}$ at the infectious focus. The upregulated B1R is now accessible for $\operatorname{des}^{A r g}{ }^{9} \mathrm{BK}$, released from the bacteria, which may contribute to a sustained inflammatory response.
IMR-90 cells. To this end, supernatants from overnight AP41 cultures were collected and incubated with PBMCs for $24 \mathrm{~h}$ followed by ELISA measurements of the IL-1 $\beta$ content in the PBMC exudates. This bacterial treatment led to a massive release of IL- $1 \beta(>80 \mathrm{ng} / \mathrm{ml})$, which was not seen in untreated cells $(<0.09 \mathrm{pg} / \mathrm{ml})$. With this information in mind it seemed likely that exudates from the streptococcal-activated PBMCs would affect surface expression of B1R on human cells. Thus, we further investigated the ability of PBMC exudates, alone or together with desArg ${ }^{9} \mathrm{BK}$, to modulate the number of available B1Rs on IMR-90 cells. For this purpose, radioligand-binding assays were performed using receptor-saturating concentrations of $\left[{ }^{3} \mathrm{H}\right] \mathrm{des} A \mathrm{Arg}^{10} \mathrm{kallidin}$, a B1R agonist, as previously described [18]. IMR-90 cells were treated for $6 \mathrm{~h}$ with PBMC exudates in the presence or absence of desArg ${ }^{9} \mathrm{BK}$. After several washing steps to remove PBMC exudates and $\operatorname{des} \operatorname{Arg}^{9} \mathrm{BK},\left[{ }^{3} \mathrm{H}\right] \mathrm{des} A \mathrm{rg}^{10}$ kallidin was added. Figure $6 \mathrm{~B}$ shows that stimulation with exudates from PBMC alone caused a 3-fold increase in B1 R agonist bind- 
ing over control. When desArg ${ }^{9} \mathrm{BK}$ was added to the incubation together with PBMC exudates the number of available B1R ligand-binding sites on the fibroblasts increased further to 8 -fold over control. Taken together the data show that AP41-secreted products induce release of IL-1 $\beta$ from human PBMCs and that these exudates together with desArg ${ }^{9} \mathrm{BK}$ have a strong upregulatory effect on B1R on human cells.

\section{Discussion}

Excessive inflammation is a hallmark of the pathology of invasive bacterial diseases. Notably, these severe complications often arise from an inappropriate host response to the infection. S. pyogenes has a multifold repertoire of virulence factors that may cause pathologic inflammatory reactions in the human host [3]. Superantigens for instance, of which streptococci express at least eleven different variants, are highly potent immunostimulatory toxins that can induce a massive activation of T lymphocytes in the absence of a presented antigen. Whereas normal antigen-presenting MHC class II complexes activate $0.01 \%$ of the T-cell population, superantigens activate up to $30 \%$ by directly cross-linking the $\mathrm{T}$-cell receptor with the MHC II, and this results in the release of pathologic levels of inflammatory cytokines including IL-1 $\beta$, IL-6, and TNF- $\alpha$ [28]. Since a massive cytokine release is a common feature of many severe bacterial infections, cytokines have been targeted for drug development. However, regardless of the target (IL-6 or TNF- $\alpha$ ), all clinical studies involving anti-cytokine treatment have so far failed [29]. The human contact system is another system that, once activated, evokes a series of inflammatory reactions [7]. Previous studies have shown that the system can be initiated on the surface of many bacterial species, including streptococci $[11,20,26,30]$, which eventually leads to the release of BK, a B2R agonist. Subsequent animal models of severe bacterial infections demonstrated that the application of contact system inhibitors has a beneficial effect $[31,32]$. However, so far, only one clinical trial targeting the contact system has been conducted. In this study, the B2R antagonist, deltibant, was tested in a multicenter, randomized, placebo-controlled trial on patients with systemic inflammatory response syndrome and presumed sepsis. It was found that the drug had no significant effect on risk-adjusted 28-day survival, even though post hoc analysis revealed a trend toward improvement [33]. However, a B1R antagonist, which would block sustained inflammatory responses, induced by the
$\mathrm{BK}$ metabolite desArg ${ }^{9} \mathrm{BK}$, or a combination of a B1R and B2R antagonist have not yet been tested.

Here, we present a novel mechanism by which streptococci convert BK from a B2R to a B1R agonist by recruiting TAFI to the bacterial surface. To achieve this, $S$. pyogenes first have to assemble and activate the contact system at their surface. This is followed by the release of BK which subsequently serves as a substrate for bacteriabound TAFI to generate desArg ${ }^{9} \mathrm{BK}$. Moreover, our studies also show that bacteria-released toxins stimulate monocytes to secrete inflammatory cytokines that in turn trigger an increase in surface-expressed B1R, the receptor for desArg ${ }^{9} \mathrm{BK}$. As depicted in figure 7, our findings suggest a chain of events, for which all critical steps are under streptococcal control. The recruitment and activation of TAFI is the crucial step in these processes since the carboxypeptidase drives the host response from a transient inflammatory stage, mediated by activation of B2Rs, to sustained inflammatory conditions involving activation of B1Rs. It should be mentioned that apart from $S$. pyogenes, S. aureus, Escherichia coli, and Salmonella spp have also been shown to generate BK at their surfaces $[26,30]$. However, we found that $S$. aureus bacteria do not interact with TAFI, and E. coli and Salmonella spp bacteria have not been reported to interact with this procarboxypeptidase. Thus, it seems likely that these latter bacteria are dependent on other mechanisms to allow conversion of BK to desArg ${ }^{9} \mathrm{BK}$, such as eukaryotic membrane-bound carboxypeptidases as shown for S. aureus [26].

Apart from targeting BK, streptococci may gain additional advantages by binding and activating TAFI. For instance, activated TAFI has been shown to cleave the anaphylotoxins $\mathrm{C} 3 \mathrm{a}$ and $\mathrm{C} 5 \mathrm{a}$, which should lead to an impaired chemotactic activity of these peptides. One can also speculate that bacteria camouflaged with a fibrin network use TAFI to prevent fibrinolysis, which may protect against attacking phagocytic cells. Thus, future work will show whether or not bacteria are using TAFI for these purposes.

A better understanding of the molecular mechanisms behind host/parasite interactions has the potential to discover important targets in the human host and ultimately new therapeutic approaches for treatment of severe infectious diseases. Here, we present a novel mechanism by which S. pyogenes of the M41 serotype may trigger sustained inflammatory reactions in the human host by TAFImediated conversion of BK to a B1R agonist and by upregulating B1Rs. Our findings therefore suggest the combined application of B1R and B2R antagonists as a promising approach to the treatment of severe infectious diseases. 


\section{Acknowledgements}

We wish to thank Monica Heidenholm and Maria Baumgarten for excellent technical assistance and Oonagh Shannon for valuable proof reading. This work was supported in part by the foundation of Alfred Österlund, Crafoord, Greta and Johan Kock, the Swedish Foundation for Strategic Research, the Vascular Wall
Programme at Lund University, the Swedish Research Council (projects 13413 and 7480), Hansa Medical AB, a VENI grant from the Netherlands Organization for Scientific Research (NWO, grant No. 916.36.104) to P.F.M, and a TOP-grant from the Netherlands Organization for Scientific Research (NWO, grant No. 912.07.002).

\section{References}

1 Sriskandan S, Altmann D: The immunology of sepsis. J Pathol 2008;214:211-223.

2 Carapetis JR, Steer AC, Mulholland EK, Weber M: The global burden of group A streptococcal diseases. Lancet Infect Dis 2005;5: 685-694.

3 Cunningham MW: Pathogenesis of group A streptococcal infections. Clin Microbiol Rev 2000;13:470-511.

4 Sriskandan S, Faulkner L, Hopkins P: Streptococcus pyogenes: insight into the function of the streptococcal superantigens. Int J Biochem Cell Biol 2007;39:12-19.

5 Lancefield RC: A serological differentiation of human and other groups of hemolytic streptococci. J Exp Med 1933;57:571-595.

6 Fischetti VA: Streptococcal M protein: molecular design and biological behaviour. Clin Microbiol Rev 1989;2:285-314.

7 Frick IM, Björck L, Herwald H: The dual role of the contact system in bacterial infectious disease. Thromb Haemost 2007;98:497502 .

8 Nordahl EA, Rydengård V, Mörgelin M, Schmidtchen A: Domain 5 of high molecular weight kininogen is antibacterial. J Biol Chem 2005;280:34832-34839.

-9 Frick IM, Åkesson P, Herwald H, Mörgelin M, Malmsten M, Nägler DK, Björck L: The contact system - a novel branch of innate immunity generating antibacterial peptides. EMBO J 2006;25:5569-5578.

10 Ben Nasr AB, Herwald H, Müller-Esterl W, Björck L: Human kininogens interact with $M$ protein, a bacterial surface protein and virulence determinant. Biochem J 1995;305:173180.

11 Ben Nasr AB, Herwald H, Renné T, Sjöbring U, Müller-Esterl W, Björck L: Absorption of kininogen from human plasma by Streptococcus pyogenes is followed by the release of bradykinin. Biochem J 1997;326: 657-660.

12 Leeb-Lundberg LMF, Marceau F, Müller-Esterl W, Pettibone DJ, Zuraw BL: International union of pharmacology. XLV. Classification of the kinin receptor family: from molecular mechanisms to pathophysiological consequences. Pharmacol Rev 2005;57: 27-77.

13 Skidgel RA, Erdös EG: Cellular carboxypeptidases. Immunol Rev 1998;161:129-141.

14 Påhlman LI, Marx PF, Mörgelin M, Lukomski S, Meijers JC, Herwald H: Thrombinactivatable fibrinolysis inhibitor binds to
Streptococcus pyogenes by interacting with collagen-like proteins A and B. J Biol Chem 2007;282:24873-24881.

15 Campbell WD, Lazoura E, Okada N, Okada $\mathrm{H}$ : Inactivation of C3a and C5a octapeptides by carboxypeptidase $\mathrm{R}$ and carboxypeptidase N. Microbiol Immunol 2002;46:131-134.

16 Myles T, Nishimura T, Yun TH, Nagashima M, Morser J, Patterson AJ, Pearl RG, Leung LL: Thrombin activatable fibrinolysis inhibitor, a potential regulator of vascular inflammation. J Biol Chem 2003;278:51059-51067.

17 Brummel KE, Butenas S, Mann KG: An integrated study of fibrinogen during blood coagulation. J Biol Chem 1999;274:2286222870.

18 Phagoo SB, Poole S, Leeb-Lundberg LF: Autoregulation of bradykinin receptors: agonists in the presence of interleukin-1beta shift the repertoire of receptor subtypes from B2 to B1 in human lung fibroblasts. Mol Pharmacol 1999;56:325-333.

19 Mattsson E, Rollof J, Verhoef J, Van Dijk H, Fleer A:Serum-induced potentiation of tumor necrosis factor alpha production by human monocytes in response to staphylococcal peptidoglycan: involvement of different serum factors. Infect Immun 1994;62:3837-3843.

20 Mattsson E, Herwald H, Cramer H, Persson K, Sjöbring U, Björck L: Staphylococcus aureus induces release of bradykinin in human plasma. Infect Immun 2001;69:3877-3882.

21 Marx PF, Hackeng TM, Dawson PE, Griffin $\mathrm{JH}$, Meijers JC, Bouma BN: Inactivation of active thrombin-activable fibrinolysis inhibitor takes place by a process that involves conformational instability rather than proteolytic cleavage. J Biol Chem 2000;275: 12410-12415.

22 Marx PF, Havik SR, Marquart JA, Bouma BN, Meijers JC: Generation and characterization of a highly stable form of activated thrombin-activable fibrinolysis inhibitor. J Biol Chem 2004;279:6620-6628.

23 Persson K, Russell W, Mörgelin M, Herwald $\mathrm{H}$ : The conversion of fibrinogen to fibrin at the surface of curliated Escherichia coli bacteria leads to the generation of proinflammatory fibrinopeptides. J Biol Chem 2003;278: 31884-31890.

24 Enquist J, Skröder C, Whistler JL, LeebLundberg LF: Kinins promote B2 receptor endocytosis and delay constitutive B1 receptor endocytosis. Mol Pharmacol 2007;71: 494-507.
25 Tropea MM, Gummelt D, Herzig MS, LeebLundberg LF: B1 and B2 kinin receptors on cultured rabbit superior mesenteric artery smooth muscle cells: receptor-specific stimulation of inositol phosphate formation and arachidonic acid release by des-Arg9-bradykinin and bradykinin. J Pharmacol Exp Ther 1993;264:930-937.

26 Bengtson SH, Phagoo SB, Norrby-Teglund A, Påhlman L, Mörgelin M, Zuraw BL, LeebLundberg LMF, Herwald H: Kinin receptor expression during Staphylococcus aureus infection. Blood 2006;108:2055-2063.

27 Schlüter H, Mentrup D, Groß I, Meyer HE, Spengler B, Kaufmann R, Zidek W: Identification of endogenous Des-Arg9-[Hyp3]-bradykinin in human plasma with post-sourcedecay matrix-assisted laser desorption/ ionization mass spectrometry. Anal Biochem 1997;246:15-19.

28 Alouf JE, Müller-Alouf H: Staphylococcal and streptococcal superantigens: molecular. biological and clinical aspects. Int $\mathrm{J} \mathrm{Med} \mathrm{Mi}-$ crobiol 2003;292:429-440.

29 Russell JA: Management of sepsis. N Engl J Med 2006;355:1699-1713.

30 Herwald H, Mörgelin M, Olsén A, Rhen M, Dahlbäck B, Müller-Esterl W, Björck L: Activation of the contact-phase system on bacterial surfaces - a clue to serious complications in infectious diseases. Nat Med 1998;4:298302

31 Pixley RA, De La Cadena R, Page JD, Kaufman N, Wyshock EG, Chang A, Taylor FB Jr, Colman RW: The contact system contributes to hypotension but not disseminated intravascular coagulation in lethal bacteremia. In vivo use of a monoclonal anti-factor XII antibody to block contact activation in baboons. J Clin Invest 1993;91:61-68.

32 Persson K, Mörgelin M, Lindbom L, Alm P, Björck L, Herwald H: Severe lung lesions caused by Salmonella are prevented by inhibition of the contact system. J Exp Med 2000; 192:1415-1424.

33 Fein AM, Bernard GR, Criner GJ, Fletcher EC, Good JT Jr, Knaus WA, Levy H, Matuschak GM, Shanies HM, Taylor RW, Rodell TC: Treatment of severe systemic inflammatory response syndrome and sepsis with a novel bradykinin antagonist, deltibant (CP0127). Results of a randomized, doubleblind, placebo-controlled trial. CP-0127 SIRS and Sepsis Study Group. JAMA 1997; 277:482-487. 